\title{
Analysis of Export Role in Forming East Java Investment
}

\author{
Ignatia Martha $\mathrm{H}^{1}$, Widiyanti Yusmaniar ${ }^{2}$ \\ ${ }^{1,2}$ (Faculty of Economics and Business, University of Pembangunan Nasional Veteran Jawa Timur)
}

\begin{abstract}
Investment is the expenditure by a person or company to buy capital assets and other production supplies to expand the producing capacity of any available economic goods or services. In order to attract investors, the government starts rearrange the policy of investment regulation taking place in Indonesia by officially produce Indonesian law number 36 on 2010 about Investment. By the increasing of investment which could increase the production capacity, it is expected to increase the productivity to produce output and valueadded, so that it would either increase the economic growth.

This research aims to find out the analysis of macro-economy in forming the investment in East Java, to find out which free variable that is the most influential towards the forming of investment in East Java. This research uses secondary data, with time series data from 2002-2011. Analysis used in this research is multiple linear regression with the variables are Interest Rate (X1), Gross Regional Domestic Product (X2), Export Quantity (X3) as the independent variables, and Investment in East Java (Y) as the dependent variable.

The result shows that Gross Regional Domestic Product are significant, but Interest rate and Export Quantity are not significantly influential in the Forming of Investment in East Java.

Keywords: Investment, Interest rate, Gross Regional Domestic Product, Export Quantity
\end{abstract}

\section{Introduction}

Indonesia is a developing country with its open economy, where in running its economy, undoubtedly there would be cooperation between the government and any private sector or even other countries. In this case, certainly Indonesia requires a huge cost to build an even and prosperous economy for its society as stated in the prefatory of 1945 Basic Law.

At this time, Indonesia could not supply all sufficient development budgets because their domestic savings could not fulfill the investment needed, the discrepancy between the domestic saving and the requirement of investment (saving investment gap) needed to reach one certain level of economic growth, requires the government to find an alternative of other finance resource. Besides getting into debt to other countries, the government could seek anyfinance resource from other countries by utilizing foreign direct investment (FDI) and portfolio foreign investment which is an investment by the foreign sides contributing in the Indonesian capital market. Sarwedi (2002) stated that finance resource from the foreign direct investment is the most potential foreign finance compared to other foreign finance resources.

FDI is more important in assuring the implementation of long term development compared to any portfolio capital; this is due to the implementation of FDI in a country would be followed by the transfer of technology, know-how, management skill, business risk which is relatively low, and more profitable. In order to increase the investor's interest, the government starts rearranging the policy of investment regulation taking place in Indonesia by officially produce Indonesian law number 36 on 2010 about Investment.

Economic development is efforts to increase the living standard of a country which is often measured by the real income level per capita. So, besides increasing real income, the economic development aims to either to increase productivity (Irawan and Suparmoko, 1997). Development oriented to the increase of per capita income usually implemented in the developing countries of which aims to solve any problems of unemployment, poverty, and the huge discrepancy of income among those developing countries.

According to Brenton and Di Mauro in Sarwedi (2002), the increasing total export value is believed to be followed by the increasing of foreign direct investment contributing in those countries' economy, because the value has a positive and significant influence towards foreign direct investment and even it could have a complementary relation towards the foreign direct investment.

The rate of Indonesian export value depends of the government role in formulating the policy and condition of domestic or international economy and even the existing domestic politics. Since 1997 until 2005, Indonesian export value totally has been in fluctuation. The total export value decreased in 1998 and 1999, 456 trillion rupiahs in 1997 decreased to 417 trillion rupiahs in 1998 and become worst to 416 trillion rupiahs in 1999. It increased to 531 trillion rupiahs in 2000 , yet decreased to 481 trillion rupiahs in 2001 . Those values showed a positive increase in 2002-2005, 488 trillion rupiahs in 2002 and 732 trillion rupiahs in 2005. 


\subsection{Problem to Discuss}

The foreign investors would consider everything before investing their capital in Indonesia. Previous researches tend to consider the influence of macro-economy factors towards the foreign direct investment to Indonesia.

The following points are the principal problems of this research based on rationale above:

1. Does the Interest rate have a role in the forming of investment in East Java?

2. Does the Gross Regional Domestic Product have a role in the forming of investment in East Java?

3. Does the Export Quantity have a role in the forming of investment in East Java?

\subsection{Goal of The Study}

Based on the rationale and the problem to discuss above, then the goal which would be achieved in this study is described as follows:

1. To find out how much the role of Interest rate would take effect towards the forming of investment in East Java

2. To find out how much the role of Gross Regional Domestic Product would take effect towards the forming of investment in East Java

3. To find out how much the role of Export Quantity would take effect towards the forming of investment in East Java

\subsection{Investment}

\section{Theoritical Framework}

Investment is one of important components in ecomonic development, encouraging the economic growth of a country or region. Basically, investment is the expenditure of a company to implement its activity, producing goods or services. The expenditure could be for buying land, manufacture, machines for production, and other expenditures (Irawan and Suparmoko, 1997)

While according to Sukirno (2004), investment could be defined as expenditure by a person or company to buy capital assets and other production supplies to expand the producing capacity available in economy. According to its type, investment is divided as follows:

a. Autonomous investment and induced investment

Autonomous investment is an investment which its size is not affected by income, but could be changed due to any other factors besides income, i.e. level of technology, the policy of entrepreneurs, etc. Induced investment is inversely proportional to autonomous investment. It could be affected by income.

b. Public Investment and Private Investment

Public investment is an investment implemented by the government. The government here refers to central or regional government (provinsial or city government), district or even village.

Private investment is the investment implemented by any private sides.

c. Gross Investment and Net Investment

Gross investment is the total investment implemented on certain time. This also could be defined as investment implemented in a country (certain region) on a certain period of time.

Net investment is the dispute between gross investment and depreciation.

d. Domestic investment and foreign investment

- Domestic investment is the investment implemented by natives

- Foreign investment is the investment implemented by foreigner

\subsection{Domestic Investment}

The domestic investment is an activity of investing to have business in Indonesia implemented by domestic investor by using domestic capital. This regulated in the Law number 25 in 2007 about Investment. Domestic investor could be implemented by the Indonesian people, state-owned company, and/or the government investing in the Indonesia region.

Business activity or any type of open business in investing, besides the closed one and open business by certain condition and the limitation of national capital ownership on company business are regulated in the President Regulation number 36 in 2010 about the Changing of Closed and Opened Business List in Certain Condition in Investment.

\subsection{Foreign Investment}

According to the Law number 1 in 1967 about Foreign Investment, foreign investment is identified as a direct foreign investment implemented based on the regulation of Indonesian Law, which means that the capital owner is directly responsible for the risk of the investment itself. Indonesian Law number 25 in 2007 as the replacement of Law number 1 in 1967 about Foreign Investment stated that Foreign Investment is an activity of 
investment to do business in Indonesia region implemented by foreign investors, whether completely using foreign capital or sharing capital with the domestic investors.

Krugman (2001) stated that foreign direct investment is an international capital flow where a company of a country expands its business in other countries. The dominant character of foreign direct investment is that it is not only involving resources transfer but also implementing control. This means that the subsidiary company does not only have financial responsibility towards the main company; it is part of the same organization structure.

President Regulation number 36 in 2010 about List of Closed Business and List of Opened Business with Requirements of Investment. There are classifications of business list of investment, which are:

1. Closed business, a certain business which is forbidden to be implemented as investment activity. These are the list of closed business in investment:
a. Farming
b. Forestry
c. Industry
d. Transportation
e. Communications and IT
f. Cultures and Tourism

The closed business could be used for non-commercial purpose such as for research and development and got permission from the responsible institution of that business.

2. Opened business with requirements is a certain business which could be implemented as investment activity based on certain requirement. The list of opened business with requirements (as stated in second appendix in President Regulation number 36 in 2010) are:

a. Business for Small Medium Enterprices

b. Partnership

c. Capital ownership

d. Special Licensing

e. $100 \%$ domestic capital

f. The ownership of capital and location

g. Special licensing and capital ownership

h. $100 \%$ domestic capital and special licensing

i. Requirements for foreign capital ownership and/or location for ASEAN investor

\section{Influential factors towards investment}

Some economists had agreed that investment depends on some factors (Sukirno, 2004:122):

1. Expectation on the future

Expectation showing that the economic situation would be better in the future such as the price level would be stable, the economic growth and the income of society would increase rapidly are the situation which would increase the investment growth. The better situation we got in the future, then the entrepreneur would get bigger profit so that they would be more motivated to invest.

2. Interest rate

Interest rate could influence the entrepreneur to decide or invest. A condition showing that if the income received from getting interest from its saving is much bigger than the profit received from investment then he/she would prefer take interest profit to invest.

3. Technology changes and development

The more existing development of technology, then the modernity activity implemented by entrepreneurs such as buying new capital goods, building new factory would finally increase investment

4. Level of national income and its changes

Investment tends to reach a better level when the national income is also getting better and on the contrary, the lower the investment is, then it would take effect to the national income.

5. The expected benefit

When those companies invest using saving or certain capital, then they would not be charged by any fee for the next period of time.

\subsection{Interest rate}

Interest rate determines kinds of investment giving profit to the entrepreneurs and could be implemented. Those entrepreneurs would just implement desire to invest when the level of capital return of the implemented investment, which is the percentage of profit they will get before reduced by the interest of 
paid money, is bigger than the interest itself. That is why in the macro-economy analysis, analysis on investment is more concerned on showing the role of interest rate in determining investment level and the cause of interest rate changes of investment and national income (Sukirno, 2004).

According to Nopirin (1996), interest rate is the fee that should be paid by the debtor for the received debt and it is a kind of requital for the creditor of the investment he/she invests. There are two kinds of interest rate; they are nominal interest rate and real interest rate. Nominal interest rate is the rate that could be investigated in the market. While real interest rate is a concept measuring the real interest rate after the nominal interest rate is reduced by the expected inflation rate.

\subsection{Gross Regional Domestic Product}

Not being a good indicator, the level of society welfare, based on the economy aspect, could be measured by using national income per capita. Gross Domestic Product could describe the national income of a country. Sukirno (2004) in his book stated that the high national income would take effect to the society income, and then the high society income itself would increase the demand towards any goods and services. Then the profit of the company would be raised and this could increase the level of investment implemented. Even in a theory of classic economy, it is described that the high society income would increase consumption so that it would either increase investment.

$\mathrm{Y}=\mathrm{C}+\mathrm{I}$

$\mathrm{Y}=$ national income of a country/region

$\mathrm{C}=$ accumulation of consumption

$\mathrm{I}=$ Investment

The concept of Gross Regional Domestic Product is basically similar to Gross Domestic Product. Thus, Gross Regional Domestic Product concerns to the regional income. Based on the data received from Central Board of Statistics (in Indonesia, it is called Badan Pusat Statistik) relating to the distribution of provinces region in Indonesia, Gross Regional Domestic Product could be defined in three definitions:

1. Based on production definition, Gross Regional Domestic Product is the amount of product value and the final service produced by any production unit in a region for a period of time, normally a year.

2. Based on income definition, Gross Regional Domestic Product is the payback received by the production factors in a production process of a region for a certain period of time (a year). The payback of those production factors is commission and salary, land rent, capital interest and profit, without any cut from income tax or other indirect taxes. In the term of Gross Regional Domestic Product, except income factor above, there are component of capital goods depreciation and net indirect tax. All those components are called gross value-added and gross regional domestic product obtained from value-added of all business field.

3. Based on expenditure definition, gross regional domestic product is the amount of all expenditures for household and private institution consumption which are not looking for profit, government consumption, and permanent capital forming of gross domestic, changes of supply and net export of a region. Net export here means the gap between export and import.

The account of gross regional domestic product uses two kinds of price; they are applied price and constant price. The price of gross regional domestic product of applied price is the value-added of goods and services accounted using applied price in the pertinent year. While constant price is accounted using the price in the certain year as the basic year.

\subsection{Export}

Export activity is a trade system by selling domestic goods to the abroad fulfilling certain requirements. Export is the total of goods and services sold by a country to other countries, including goods, insurance, and services in certain years (Priadi, 2000). Export is good and service produced in domestic and sold widely abroad (Mankiw, 2006).

The definition of export is good and service produced in domestic and bought by foreigner of any countries (Samuelson and Nordhaus, 2004: 325). What is meant by export is removing goods and from society circulation and sending them abroad as the Government regulation stated and expecting payment in a foreign exchange (Amir, 1995:209).

According to Amir (1995:30), the obstacle of export is everything obstructive towards the export process, whether from domestic or by the importer itself. These are the examples of those obstacles:

1. Complicated bureaucracy, obstructing the licensing process

2. Illegal fee (out of regulation) causing the economy fee turns high, weakening the competitiveness.

3. Lack of national discipline, breaking the productivity, integrity, and the reliability of national exporter. The export obstacle intentionally implemented by the importer country: 
- Common External Tariff, the incoming tax tariff is high, determined by European countries, the member of joint market; applying it to other countries, including Indonesia.

- British Commonwealth Preference, a special import incoming tax tariff given by England to the ex-dominion of England such as Australia, Singapore, Canada, etc. Then it could not be applied to other countries, including Indonesia.

- Quota system for output of industry and farming import, which is the limitation for the Indonesia export development.

- The requirement of certification and excessive import procedure to cause difficulties on import applied by developed countries such as United States of America.

Export and Foreign Direct Investment are two related things in the economic development. Thus, if these two components separated, then it would be emerging a new problem, specifically if they are related to motivation or MNCs activity in a country. This relates to multiplier effect of employing domestic working force. The effect of MNCs operation towards the working force and this wage is still being argued by some experts. What has been done all this time is observing whether the relation between foreign direct investment and the export as the complementary or substitution (Graham, 1996, Brenton and Di Mauro, 1999).

\subsection{Operational Definition}

\section{Research Methodology}

Several definitions of operational research variables measurement are based on theory and empirical data, where the existing variables show that there are functional relations defining the dependent variables on independent variables specifically. In this research, the used variables could be differed by two kinds:

a. Dependent variable (Y), a variable which is needed to be explained (explained variable). The dependent variable in this research is the investment in East Java in 2002-2011.

b. Independent variable, an explaining variable (explanatory variable). The independent variable in this research are:

(X1) Interest rate, the amount of interest rate decided by Central Bank for investment and should be paid in a certain period of time.

(X2) Gross Regional Domestic Product, the amount of final good and service value produced by any production units in a region which is East Java region in a certain period of time, normally a year

(X3) Export Quantity, the amount of volume sent from East Java harbor to the abroad as regulated by the government and expecting the foreign currency for its payment.

\subsection{Variable Measurement}

Interest rate, Gross Regional Domestic Product, and the export here are the independent variables that would not be affected by other variables. The interest rate is written in percentage value (\%). Gross Regional Domestic Product is written in million rupiahss (IDR 000.000). While, export quantity is written in kilograms value $(\mathrm{kg})$. If this variable is increasing or decreasing, it would probably influence the dependent variable which is stated in million rupiahss (IDR 000.000).

The used data is the secondary data obtained from books published by any related institutions. Those institutions are the Central Bank of Indonesia (BI) located in Surabaya, the Central Board of Statistics (BPS) located in Surabaya, and the Investment Coordinating Board (BKPM)

\subsection{Analysis Technique}

The collected data is then being analyzed by using quantitative method based on the existing theory. Double linear regression analysis is a kind of method used in analyzing the influential relation between independent variable and dependent variable. This analysis is using OLS (Ordinary Least Square) method with SPSS version 13 that could be written as follows (Nachrowi and Usman, 2005:315):

$$
\mathrm{Y}=\beta 0+\beta 1 \mathrm{X} 1+\beta 2 \mathrm{X} 2+\beta 3 \mathrm{X} 3+\mathrm{ei}
$$

Where:

$\begin{array}{lll}\mathrm{Y}= & \text { Investment } \\ \mathrm{X} 1= & \text { Interest rate } \\ \mathrm{X} 2= & \text { GRDP } \\ \mathrm{X} 3= & \text { Export Quantity } \\ \beta 0= & \text { Constant } \\ \beta 1, \beta 2, \beta 3 & \text { Regression Coefficient } \\ \mathrm{ei}= & \text { Intruder Variable }\end{array}$




\subsection{Classical Assumption}

\section{Result}

a. Autocorrelation

Based on the analysis result, then in this regression model, there should not be any autocorrelation because the value of DW Test obtained which are 2.361 is on 4-dU and 4-dL which means that it is in doubt.

b. Multi Collinearity

This is the result of multi collinearity test

Table 1. Multi collinearity test

\begin{tabular}{|l|l|l|l|}
\hline Variable & Tolerance & VIF & Requirement \\
\hline Interest rate (X1) & 0.229 & 4.364 & $<10$ \\
\hline GRDP (X2) & 0.167 & 5.981 & $<10$ \\
\hline Export Quantity (X3) & 0.289 & 3.462 & $<10$ \\
\hline
\end{tabular}

Based on the table above, it could be seen that all variables are less than 10 . Then it could be concluded that there is no multi collinearity in this regression.

c. Heteroscedasticity

The proof of the existence of heteroscedasticity could be seen on the table below:

Table 2 : Heteroscedasticity test

\begin{tabular}{|l|c|c|c|}
\hline \multicolumn{1}{|c|}{ Variable } & Correlation & Sig & Requirement \\
\hline Interest rate (X1) & 0.067 & 0.427 & $>0.05$ \\
\hline GRDP (X2) & -0.103 & 0.388 & $>0.05$ \\
\hline Export Quantity (X3) & -0.079 & 0.414 & $>0.05$ \\
\hline
\end{tabular}

Based on the result of the table above, it shows that Interest rate (X1), GRDP (X2) and export quantity (X3) fulfill the assumption of homoscedasticity. Based on the test implemented above, it can be concluded that on the research model there is no violation of classic assumption.

\subsection{Multiple Linear Regression Analysis}

Table 3 : Result of Multiple Linear Regression Analysis by using SPSS Program

\begin{tabular}{|c|c|c|c|c|}
\hline Independent variable & Regression coefficient & $\mathrm{t}_{\text {count }}$ & $r_{\text {partial }}$ & Sig \\
\hline Interest rate (X1) & 3812777563.812 & 1.270 & 0.460 & 0.251 \\
\hline GRDP (X2) & 295.544 & 2.343 & 0.691 & 0.058 \\
\hline Export Quantity(X3) & 2.749 & 0.842 & 0.325 & 0.432 \\
\hline Dependent Variable (Y) & : Investment & & & \\
\hline Correlation Coefficient Constant & :- 146816724695 & & & \\
\hline (R) & $: 0.896$ & & & \\
\hline Determination Coefficient $\left(\mathrm{R}^{2}\right)$ & $: 0.802$ & & & \\
\hline Adjusted R Square & $: 0.704$ & & & \\
\hline$t_{\text {table }}$ & $: 2.228$ & & & \\
\hline
\end{tabular}

Based on the result above, the equation of Multiple Linear Regression is described as follows:

$\mathrm{Y}=\beta 0+\beta 1 \mathrm{X} 1+\beta 2 \mathrm{X} 2+\beta 3 \mathrm{X} 3$

$Y=-146816724695.234+812777563.812 X 1+295.544 X 2+2.749 X 3$

Based on the equation above, it could be explained as follows:

$\beta 0=$ Constant $=\mathbf{- 1 4 6 8 1 6 7 2 4 6 9 5 . 2 3 4}$

This shows how the other factors could affect investments; it means that when the independent variables such as Interest rate (X1), GRDP (X2), and Export Quantity (X3) are constant, then the investment in East Java would be decreasing on IDR 146,816,724,695.234 


\section{$\beta 1=$ Regression Coefficient $X 1=\mathbf{3 8 1 2 7 7 7 5 6 3 . 8 1 2}$}

The result above shows that the Interest rate factor (X1) not significant effect; this means that when the Interest rate is increasing on $1 \%$, then the investment in East Java would either increase IDR $3,812,777,563.812$ with the assumption that the $\mathrm{X} 2$ and $\mathrm{X} 3$ independent variable are constant. Then this is not compatible to Keynes theory "When the Interest rate is expected to be decreased, then people would like to have properties on obligation rather on cash, because obligation is not the only one that gives certain income per period". Due to the different condition on the field, although the interest rate increases, the investment would be increasing. This is because the investors consider other factors such as low wage of labors, big market segment and wide land for production.

\section{$\beta 2=$ Regression Coefficient X2 $=295.544 *$}

The result above shows that the Gross Regional Domestic Product (X2) factor has a positive effect; this means that when there is IDR 1,000,000 increase on GRDP, then the investment in East Java would increase IDR 295.544 with assumption the other independent variables are constant. Then this result is compatible to research implemented by Sarwedi (2002) who stated that Gross Domestic Product (GDP) has a real effect towards Foreign Direct Investment (FDI)

\section{$\beta 3=$ Regression Coefficient X3 $=2,749$}

This shows that Export Quantity (X3) not significant effect; this means that when there is $1 \mathrm{~kg}$ increase on export quantity, then the investment in East Java would increase IDR 2.749 with assumption that other independent variables are constant.

$\mathrm{R}^{2}$ (determination coefficient) $=0.802$ and Adjusted $\mathrm{R}^{2}=0.704$. This value shows the capability of dependent variable to influence independent variable as big as 0.704; this means that Investment $(\mathrm{Y})$ could be explained by the variation of Interest rate, GRDP, and Export Quantity variables until $70.4 \%$. While the rest of it as big as $29.6 \%$ could be explained by other variables. While the coefficient correlation $(\mathrm{R})=0.896$ means that the close relation between independent and dependent variable is very strong.

\subsection{Analysis of Variance (ANOVA)}

In order to find out the compatibility of model between research and analysis tool then the F test is used.

Table 4 : Analysis of Variance (ANOVA)

\begin{tabular}{|c|c|c|c|c|c|}
\hline $\begin{array}{c}\text { Variant } \\
\text { Resource }\end{array}$ & Amount of Quadrate & $\mathrm{df}$ & Mean Quadrate & $\mathrm{F}_{\text {count }}$ & $\mathrm{F}_{\text {table }}$ \\
\hline Regression & 9223372036854776 & 3 & 9223372036854776 & 8,123 & 4.76 \\
\hline Residue & 9223372036854776 & 6 & 9223372036854776 & & \\
\hline Total & 9223372036854776 & 9 & & & \\
\hline
\end{tabular}

The analysis of variance result of $\mathrm{F}$ test shows a significant result; it could be concluded that the tool of double regression analysis which is used as an analysis tool is compatible for this research, seen from the number of Fcount $=8.123$ with Sig. $0.016<0.05$ : positive significant, means that at whole, the interest rate (X1), GRDP (X2) and export quantity (X3) variables could explain the variable changes of Investment (Y).This analysis result shows that the regression model used for this technique is compatible.

\subsection{Conclusion}

\section{Conclusion And Limitation}

The interest rate (X1) with 5\% significance level has no real effect towards investment in East Java. This is due to the increasing or the decreasing of interest rate is not being an important consideration for investors to invest. They just want to have the better exchange for everything they have expended for their investment. Besides, they would invest their capital in East Java although the interest rate is raising, because they would rather see other factors such as low wage, big market segment and wide land for production activity. Besides, they would invest their capital in East Java although the interest rate is raising, because they would 
rather see other factors such as low wage, big market segment and wide land for production activity.This is not compatible with theory of Keynes "When the Interest rate is expected to be decreased, then people would like to have properties on obligation rather on cash". This is either explained by the Head of Board of Investment in East Java Province Government that "The high contribution of investment in East Java cannot be separated by the success of our (East Java Government) promotion to the abroad. This finally motivates the foreign investor to invest in East Java and it increases as big as 438.13\%" (Radar Surabaya, 8th May 2013, page 1).

Gross Regional Domestic Product (X2) has no real effect towards the investment in East Java on 5\% level. Yet, it has real and significant effect on $10 \%$ level. Based on the research, there is an accurate information stating that East Java is the activator of Indonesian economy and is the potency of economy market so that the investors are willing to invest their capital in East Java because East Java could fulfill the industry material needed, which are: processing of food, chemistry and pharmacy, machine metal, electronic, sheet industry, rubber, plastic, and textile (Radar Surabaya, 8th May 2013, page 1). This is compatible to what Sukirno has stated that "High national income would give an effect to the society's income, and then it will increase the demand of goods and services. The profit of a company would increase and this would cause more investments." When the GDP variable is increasing, then the Foreign Investment would also increase. This is compatible to the research implemented by Amiruddin, et al (2005) that the Gross Regional Domestic Product has affected Foreign Investment.

Export quantity (X3) on 5\% level has no real effect towards investment in East Java. This is because the export activity is just for fulfilling the domestic need so that it does not increase the investment in East Java. This is either probably due to the incoming investment and developed for the domestic necessity due to huge population. This is a proof that the investors see this as an opportunity of domestic market, specifically in East Java.

Based on the research above, it could be seen that the most dominant influential variable towards the investment in East Java is Gross Regional Domestic Product; this is shown by $\mathrm{R}^{2}=0,6912$ which is bigger than $\mathrm{R}^{2}$ on other independent variables.

\subsection{Limitation}

This research is only examining the Interest rate, Gross Regional Domestic Product, and Export Quantity towards the investment in East Java (Y). for the next research, it is better to analyze the list of closed business field in the investment field as stated in President Regulation number 36 in 2010 and include other factors such as licensing, policy and business climate and also the research period to get the best result of research.

\section{Journal Papers:}

\section{References}

[1] Amiruddin, Analisis Faktor-Faktor Yang Mempengaruhi Perkembangan Investasi Dalam Pembangunan Daerah Sumatera Utara, 2005. Access on 05-02-2013:09.56

[2] Brenton, P, dan Di Mauro, F, "The Potential Magnitude And Impact Of FDI How To CEECS”, Journal Of Economic Integration, Vol. 14 No. 1 PP 59-74, 1999.

[3] Sarwedi, Investasi Asing Langsung Di Indonesia Dan Faktor Yang Mempengaruhinya, 2002. Access on 05-02-2013:06.43

[4] Priadi, Utomo Yuni, Ekspor Mendorong Pertumbuhan atau Pertumbuhan Mendorong Ekspor, Jurnal Manajemen. Vol.1, No.1. UII, Yogyakarta, 2000

\section{Books:}

[5] Amir, MS, Pengantar Bisnis Ekspor Dan Impor, Edisi Revisi, Lembaga PPM dan PT. Pustaka Binaman Pressindo, Jakarta, 1995.

[6] Anonim, Jatim Dalam Angka, East Java Central Board of Statistics (BPS), Surabaya, berbagai tahun

[7] Anonim, Pertumbuhan Investasi di Indonesia, Investment Coordinating Board (BKPM), berbagai tahun

[8] Anonim, Laporan Triwulanan, Central Bank of Indonesia (Bank Indonesia), berbagai tahun

[9] Krugman et al, The Spatial Economy: Cities, Regions and International Trade, MIT Press, 2001.

[10] Mankiw, N. Gregory, Principles of Macroeconomics, Fourth Edition. Thomson, 2006.

[11] Nachrowi, D. dan Hardius Usman, Pendekatan Populer Dan Praktis Ekonometrika Untuk Analisis Ekonomi Dan Keuangan. LPFE UI, Jakarta, 2005

[12] Nopirin, Ekonomi Moneter, BPFE UGM, Yogyakarta, 1996.

[13] Peraturan Presiden Republik Indonesia Nomor 36 Tahun 2010 (President Regulation number 36 in 2010), Tentang Perubahan Daftar Bidang Usaha yang Tertutup dan Bidang Usaha yang Terbuka dengan Persyaratan di Bidang Penanaman Modal

[14] Samuelson, Paul A, dan William D, Nordhaus, Ilmu Makro Ekonomi, Edisi Ketujuh Belas, PT. Media Global Edukasi, Jakarta, 2004.

[15] Suparmoko, dan Irawan, Ekonomi Pembangunan, BPFE UGM, Yogyakarta, 1997

[16] Sukirno, Sadono, Makro Ekonomi : Teori Pengantar, Edisi Ketiga, PT. Raja Grafindo Persada, Jakarta, 2004.

[17] Undang Undang Republik Indonesia Nomor 1 tahun 1967 (Law number 1 in 1967), Tentang Penanaman Modal Asing 
[18] Undang Undang Republik Indonesia Nomor 25 Tahun 2007 (Law number 25 in 2007), Tentang Penanaman Modal

\section{Proceedings Papers:}

[19] Graham, E. M, “On Realization Among FDI And International Trade In The Manufacturing Sector : Empirical Result For The United State And Japan, WTO”. Staf Working Paper Rd, 1996.

[20] Radar Surabaya, $8^{\text {th }}$ May 2013 